University of Nebraska - Lincoln

DigitalCommons@University of Nebraska - Lincoln

Agronomy \& Horticulture -- Faculty Publications

Agronomy and Horticulture Department

2020

Adjusting corn nitrogen management by including a mineralizable-nitrogen test with the preplant and presidedress nitrate tests

Jason Clark

Fabián G. Fernández

Kristen S. Veum

James J. Camberato

Paul R. Carter

See next page for additional authors

Follow this and additional works at: https://digitalcommons.unl.edu/agronomyfacpub

Part of the Agricultural Science Commons, Agriculture Commons, Agronomy and Crop Sciences Commons, Botany Commons, Horticulture Commons, Other Plant Sciences Commons, and the Plant Biology Commons

This Article is brought to you for free and open access by the Agronomy and Horticulture Department at DigitalCommons@University of Nebraska - Lincoln. It has been accepted for inclusion in Agronomy \& Horticulture -Faculty Publications by an authorized administrator of DigitalCommons@University of Nebraska - Lincoln. 


\section{Authors}

Jason Clark, Fabián G. Fernández, Kristen S. Veum, James J. Camberato, Paul R. Carter, Richard

Ferguson, David W. Franzen, Daniel E. Kaiser, Newell R. Kitchen, C. A.M. Laboski, Emerson Nafziger, Carl J.

Rosen, John E. Sawyer, and John F. Shanahan 
DOI: $10.1002 /$ agj2.20228

A R T I CLE

Soil Fertility \& Crop Nutrition

\title{
Adjusting corn nitrogen management by including a mineralizable-nitrogen test with the preplant and presidedress nitrate tests
}

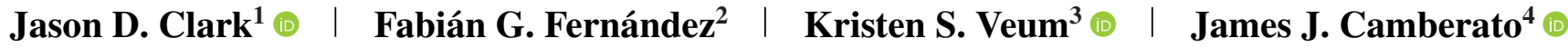

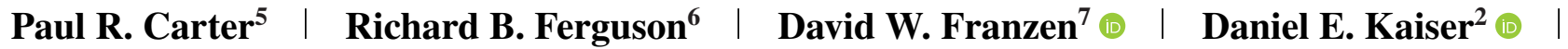 \\ Newell R. Kitchen ${ }^{3}$ (i) ｜ Carrie A. M. Laboski ${ }^{8} \quad$ Emerson D. Nafziger ${ }^{9} \quad$ Carl J. Rosen ${ }^{2}$ | \\ John E. Sawyer ${ }^{10}$ @ | John F. Shanahan ${ }^{11}$ \\ ${ }^{1}$ South Dakota State Univ., 1148 Medary Ave., Brookings, SD 57007, USA \\ ${ }^{2}$ Univ. of Minnesota, 1991 Upper Buford Circle, St. Paul, MN 55108, USA \\ ${ }^{3}$ USDA-ARS Cropping Systems and Water Quality Research Unit, Columbia, MO 65211, USA \\ ${ }^{4}$ Purdue Univ., 915 W. State St., West Lafayette, IN 47907, USA \\ ${ }^{5} 13801$ Summit Drive, Clive, IA 50325, USA \\ ${ }^{6}$ Univ. of Nebraska, Keim 367, Lincoln, NE 68583, USA \\ ${ }^{7}$ North Dakota State Univ., PO Box 6050, Fargo, ND 58108, USA \\ ${ }^{8}$ Univ. of Wisconsin-Madison, 1525 Observatory Dr., Madison, WI 53706, USA \\ ${ }^{9}$ Univ. of Illinois, 1102 S. Goodwin, Urbana, IL 61801, USA \\ ${ }^{10}$ Iowa State Univ., 3208 Agronomy Hall, 716 Farm House Lane, Ames, IA 50011, USA \\ ${ }^{11}$ Soil Health Institute, 6807 Ridge Rd, Lincoln, NE 68512, USA
}

\section{Correspondence}

Jason D. Clark, South Dakota State Univ., 1148 Medary Ave., Brookings, SD 57007, USA.

Email: Jason.D.Clark@sdstate.edu

Funding information

DuPont Pioneer

\begin{abstract}
The anaerobic potentially mineralizable $\mathrm{N}(\mathrm{PMN})$ test combined with the preplant (PPNT) and presidedress (PSNT) nitrate tests may improve corn (Zea mays L.) $\mathrm{N}$ fertilization predictions. Forty-nine corn $\mathrm{N}$ response experiments (mostly corn following soybean [Glycine $\max ($ L.) Merr.]) were conducted in the U.S. Midwest from 2014-2016 to evaluate the ability of the PPNT and PSNT to predict corn relative yield (RY) and $\mathrm{N}$ fertilizer over- and under-application rates when adjusted by PMN. Before planting and $\mathrm{N}$ fertilization, PPNT (0-30, 30-60, and 60-90 cm) and PMN $(0-30 \mathrm{~cm})$ samples were obtained. In-season soil samples were obtained at the V5 development stage for PSNT $(0-30,30-60 \mathrm{~cm})$ in all $\mathrm{N}$ rate treatments and PMN $(0-30 \mathrm{~cm})$ in only the 0 and $180 \mathrm{~kg} \mathrm{~N}^{-1}$ preplant $\mathrm{N}$ treatments. Increasing $\mathrm{NO}_{3}-\mathrm{N}$ sampling depths beyond $30 \mathrm{~cm}$ with or without PMN
\end{abstract}


improved RY predictability marginally ( $\mathrm{R}^{2}$ increase up to 0.20 ) and reduced overand under-application frequencies up to $14 \%$. Including PMN (preplant only) with PPNT or PSNT improved RY predictability minimally ( $\mathrm{R}^{2}$ increase up to 0.10 ) only for coarse- and medium-textured soils, but $\mathrm{N}$ fertilizer over- and under-application frequencies were not substantially reduced $(\leq 12 \%)$. These marginal improvements in RY predictability and $\mathrm{N}$ fertilizer over- and under-application frequencies, regardless of the variables used (e.g., fertilization, sampling depth, soil texture, and growing degree-day categories), demonstrate that including $\mathrm{PMN}$ with soil $\mathrm{NO}_{3}-\mathrm{N}$ alone does not improve corn $\mathrm{N}$ fertilization need predictions enough to recommend their use.

\section{1 | INTRODUCTION}

Improving soil testing and the use of soil tests used in making management decisions can improve corn fertilizer- $\mathrm{N}$ rate guidelines (Dinnes et al., 2002). Improved $\mathrm{N}$ management guidelines can improve economic profits for farmers and reduce potential negative environmental effects including reduced air quality, global warming, and water pollution (Cavigelli et al., 2012; Helmers, Zhou, Baker, Melvin, \& Lemke, 2012; McCasland, Trautmann, Porter, \& Wagenet, 2012; Ribaudo et al., 2011; Struffert, Rubin, Fernández, \& Lamb, 2016; USEPA, 2018). To be most effective in improving fertilizer$\mathrm{N}$ rate guidelines, soil tests used to make $\mathrm{N}$ management decisions will likely need to account for both plant-available inorganic $\mathrm{N}$ and $\mathrm{N}$ mineralized during the growing season. The preplant (PPNT) and presidedress (PSNT) nitrate tests are commonly used to assess inorganic $\mathrm{N}$, and the anaerobic potentially mineralizable $\mathrm{N}$ test (PMN) is commonly used to assess mineralizable N (Magdoff, Ross, \& Amadon, 1984; Waring \& Bremner, 1964). Using these soil tests together has the potential to improve fertilizer- $\mathrm{N}$ rate guidelines.

The PPNT is taken early in the spring before any organic or inorganic $\mathrm{N}$ amendments are applied to the soil to measure the amount of $\mathrm{NO}_{3}-\mathrm{N}$ remaining in the soil from the previous season. This soil sample timing is attractive to many corn growers because it can avoid time and labor constraints that occur later in the season. The PSNT measures soil $\mathrm{NO}_{3}-\mathrm{N}$ when corn plants are $15-30 \mathrm{~cm}$ tall. The timing of this soil test is important because the value represents the concentration of soil $\mathrm{NO}_{3}-\mathrm{N}$ as an index of available $\mathrm{N}$ for corn based on soil and weather conditions just prior to the rapid $\mathrm{N}$ uptake period for corn (Magdoff et al., 1984). Studies have shown that both the PPNT and PSNT are positively related to RY (Barbieri, Echeverría, \& Saínz Rozas, 2008; Bast, Mullen, Eckert, \& Thomison, 2012; Binford, Blackmer, \& Cerrato, 1992; Bundy \& Andraski, 1995; Bundy et al., 1994, 1999; Fox, Roth, Iversen, \& Piekielek, 1989; Sainz Rozas, Echeverria, Studdert, \& Dominguez, 2000; Schmitt,
Randall, \& Rehm, 2002; Zebarth, Younie, Paul, \& Bittman, 2002). One of the strengths of these soil tests is that they can be used to determine the critical soil nitrate content (CSNC) where values below the CSNC warrant $\mathrm{N}$ fertilization, whereas values above require no $\mathrm{N}$ input. The utility of these nitrate tests are judged on their capacity to correctly identify the CSNC and separate responsive and nonresponsive sites (Bundy, Walters, \& Olness, 1999).

The PPNT has been successfully used primarily in semiarid and arid environments along with semi-humid areas and areas with extended periods of frozen soil when $\mathrm{N}$ loss potential is minimal (Bundy \& Andraski, 1995; Bundy et al., 1994; Rehm, Schmitt, \& Eliason, 2002; Schmitt \& Randall, 1994). However, the PPNT provided less utility in many parts of the U.S. Midwest where excessive rainfall was common after soil sampling, which resulted in large $\mathrm{N}$ losses and overestimation of plant-available N (Cela, Berenguer, Ballesta, Santiveri, \& Lloveras, 2013). The PSNT was less reliable when soil temperatures were lower than normal up to the time of soil sampling (Andraski \& Bundy, 2002) and in areas where $\mathrm{N}$ is highly susceptible to loss such as coarse-textured soils and in years where large rain events occurred close to soil sampling (Magdoff, 1991; Yost, Russelle, \& Coulter, 2013). Reduced RY predictability with the PPNT and PSNT also occurred when organic amendments were applied recently to the soil or the previous crop was a legume (Andraski \& Bundy, 2002; Bundy et al., 1999; Cela et al., 2013).

Reduced RY predictability with the PPNT and PSNT occurs because these tests only account for the inorganic $\mathrm{N}$ present at the time of soil sampling and not for $\mathrm{N}$ that is mineralized during the remainder of the growing season. Accounting for mineralizable $\mathrm{N}$ over the entire growing season is important because mineralization processes can provide anywhere from 20-100\% of corn N needs (Broadbent \& Hauck, 1984; Khan, Mulvaney, \& Hoeft, 2001; Morris et al., 2018; Roberts, Ross, Norman, Slaton, \& Wilson, 2011; Ros, Temminghoff, \& Hoffland, 2011; Yost, Coulter, Russelle, Sheaffer, \& Kaiser, 2012). Using a soil test that 
estimates $\mathrm{N}$ mineralization in conjunction with the PPNT and PSNT might improve the predictability of RY and reduce $\mathrm{N}$ fertilizer over- and under-application rates.

The PMN test has been used as an $\mathrm{N}$ mineralization index in Argentina to divide soils into high and low PMN groups, which resulted in a $12 \%$ improvement in RY predictability with the PSNT for low PMN sites (Sainz Rozas, Calvino, Echeverría, Barbieri, \& Redolatti, 2008). The inclusion of PMN as a variable with PPNT and PSNT also improved corn grain yield predictability by $5-37 \%$ in the control (unfertilized) plots with the greatest improvements coming from fields that had cool early spring temperatures and lower PSNT values (Orcellet, Reussi Calvo, Sainz Rozas, Wyngaard, \& Echeverría, 2017). Despite the potential utility shown when coupling the PMN test to the PPNT and PSNT, similar studies are lacking in the U.S. Midwest.

While the PMN test may be useful to improve the PPNT and PSNT in the U.S. Midwest, it may be important to explore a few additional considerations. Nitrogen mineralization indices have been reported to change throughout the growing season depending on variables such as crop rotation, management practices, precipitation, temperature, and soil $\mathrm{C}$ to $\mathrm{N}$ ratios (Clark et al., 2019; Culman, Snapp, Green, \& Gentry, 2013). Nitrogen fertilization has also influenced $\mathrm{N}$ mineralization by increasing PMN from in-season soil samples with organic $\mathrm{C}>21 \mathrm{~g} \mathrm{~kg}^{-1}$ and clay content $<9.5 \%$ and decreasing PMN under the opposite conditions (Clark et al., 2020). Evaluations have not yet occurred determining whether PMN from different in-season sample timings or those from fertilized soil in conjunction with PPNT and PSNT can improve RY predictability. Accounting for the potential effect of soil sample timing and $\mathrm{N}$ fertilizer on PMN may have important practical implications for $\mathrm{N}$ fertilizer management. Therefore, the objective of this study was to evaluate RY predictability and frequency of over- and under-applying $\mathrm{N}$ fertilizer with the PPNT and PSNT in conjunction with PMN from different soil sample timings and $\mathrm{N}$ fertilizer rates under contrasting soil and weather conditions across the U.S. Midwest.

\section{2 | MATERIALS AND METHODS}

\section{1 | Experimental design}

This study was conducted across eight U.S. Midwestern states: Illinois, Indiana, Iowa, Minnesota, Missouri, Nebraska, North Dakota, and Wisconsin. Two or three experimental sites were established in each state each year in 2014-2016, resulting in 49 site-years of data. Kitchen et al. (2017) contains detailed descriptions of the research protocol, agronomic practices, and the soil properties of each site-year. All experimental sites used the same randomized complete block

\section{Core Ideas}

- Including an $\mathrm{N}$ mineralization estimate plus a soil $\mathrm{NO}_{3}-\mathrm{N}$ measurement improved RY predictability for only coarse- and medium-textured soils.

- Including an $\mathrm{N}$ mineralization estimate with soil $\mathrm{NO}_{3}-\mathrm{N}$ did not reduce $\mathrm{N}$ fertilizer over- and underapplication rates.

- Partitioning soils by texture or temperature improved relative yield (RY) predictability.

- Critical soil nitrate content varied substantially depending on soil texture and temperature.

design with four replications, $\mathrm{N}$ fertilizer treatments, and soil, plant, and weather data collection methods. Eight $\mathrm{N}$ rate application treatments created a complete grain yield response to single- $\mathrm{N}$ applications by applying $\mathrm{N}$ rates at planting from 0 to $315 \mathrm{~kg} \mathrm{ha}^{-1}$ in $45 \mathrm{~kg} \mathrm{ha}^{-1}$ increments. Nitrogen fertilizer was broadcast on the soil surface using ammonium nitrate ( $340 \mathrm{~g} \mathrm{~N} \mathrm{~kg}^{-1}$ ). Ammonium nitrate is no longer a commonly used fertilizer; however, results show when different forms of $\mathrm{N}$ fertilizers are applied correctly, the response of corn is similar (Fernández, Nafziger, Ebelhar, \& Hoeft, 2009). Further, ammonium nitrate was used as it was expected to be suitable for surface application, provide a uniform broadcast application allowing for soil $\mathrm{NO}_{3}-\mathrm{N}$ and $\mathrm{NH}_{4}-\mathrm{N}$ evaluation shortly after application, and perform more similarly across the environmental conditions in our study region (Kitchen et al., 2017).

\section{2 | Soil sampling and analysis}

Soil characterization sampling was completed before planting at each experimental site by obtaining a $90-\mathrm{cm}$ deep soil core and dividing it by horizons. These soil samples were evaluated for bulk density, soil texture, total organic $\mathrm{C}$ by dry combustion (Nelson \& Sommer, 1996), soil organic matter by loss-on-ignition (Soil Survey Staff, 2014), and total N using methods described in Kitchen et al. (2017). Weighted averages of these soil measurements were calculated for three depth increments $(0-30,30-60$, and $60-90 \mathrm{~cm})$ using the depth of each horizon within each depth increment.

Soil samples for $\mathrm{NO}_{3}-\mathrm{N}$ content were obtained from each replication before planting and fertilization (PPNT) and at the V5 \pm 1 corn development stage from each $0 \mathrm{~kg} \mathrm{~N}$ $\mathrm{ha}^{-1}$ plot (PSNT) and each N-fertilized plot (45-315 kg N $\left.\mathrm{ha}^{-1}\right)$. Preplant soil samples were obtained using a ten-core composite soil sample (1.9-4.0 cm i.d.; 0-30, 30-60, and 60-90 cm depths) and V5 soil samples were obtained using 
a six-core composite soil sample (1.9-cm i.d.; 0-30 and $30-60 \mathrm{~cm}$ depths). These preplant and V5 soil samples were dried $\left(\leq 32^{\circ} \mathrm{C}\right)$ and ground to pass through a 2-mm sieve. Nitrate-N was extracted using $0.2 \mathrm{~mol} \mathrm{~L}^{-1} \mathrm{KCl}$ (Saha, Sonon, $\&$ Biswas, 2018) and $\mathrm{NO}_{3}-\mathrm{N}$ concentration was quantified using the cadmium reduction method with a modified Technicon AutoAnalyzer (SEAL Analytical, Inc., Fareham, UK) (Gelderman \& Beegle, 2015). Bulk density values from each replication and 30-cm depth increment were used to convert soil $\mathrm{NO}_{3}-\mathrm{N}$ concentrations ( $\mathrm{mg} \mathrm{NO}_{3}-\mathrm{N} \mathrm{kg}^{-1}$ to $\mathrm{kg}$ $\mathrm{NO}_{3}-\mathrm{N} \mathrm{ha}^{-1}$ ). The soil available $\mathrm{N}$ content was calculated as PPNT plus $\mathrm{N}$ fertilizer rate applied to each plot [PPNT + N rate from $\left.0-315 \mathrm{~kg} \mathrm{ha}^{-1}\left(\mathrm{PPNT}_{\mathrm{N}}\right)\right]$ and as soil $\mathrm{NO}_{3}-\mathrm{N}$ at V5 from the zero-N and $\mathrm{N}$ fertilized plots $\left(\mathrm{PSNT}_{\mathrm{N}}\right.$ ) following the approach used by Cela et al. (2013).

The PMN test was run on a subset of soil samples $(0-30 \mathrm{~cm})$ that included (1) preplant soil sampling with $0 \mathrm{~kg} \mathrm{~N} \mathrm{ha}^{-1}$, (2) V5 soil sampling with $0 \mathrm{~kg} \mathrm{~N} \mathrm{ha}^{-1}$, and (3) V5 soil sampling with $180 \mathrm{~kg} \mathrm{~N} \mathrm{ha}^{-1}$ as described in Clark et al. (2019). Briefly, PMN was quantified by determining extractable $\mathrm{NH}_{4}-\mathrm{N}$ in the soil by $2 \mathrm{~mol} \mathrm{~L}^{-1} \mathrm{KCl}$ and subtracting it from the extractable $\mathrm{NH}_{4}-\mathrm{N}$ after the soil was incubated in an anaerobic environment for $7 \mathrm{~d}$ at $40^{\circ} \mathrm{C}$ (i.e. $\mathrm{PMN}=\mathrm{NH}_{4}-\mathrm{N}$ after incubation $-\mathrm{NH}_{4}-\mathrm{N}$ before incubation) (Bundy \& Meisinger, 1994). Bulk density values from the $0-30 \mathrm{~cm}$ depth were used to convert PMN concentrations ( $\mathrm{mg} \mathrm{kg}^{-1}$ to $\mathrm{kg} \mathrm{ha}^{-1}$ ).

\section{3 | Plant sampling and analysis}

All plants in the middle two rows of each experimental unit were harvested to determine grain yield (adjusted to $155 \mathrm{~g}$ $\mathrm{kg}^{-1}$ moisture). Relative yield was calculated for each site by dividing the yield of each $\mathrm{N}$ rate treatment by the mean yield of the $\mathrm{N}$ rate treatment that yielded the highest and multiplying the value by 100 to express the result as a percentage of the yield from the highest yielding $\mathrm{N}$ rate treatment.

\section{$2.4 \mid$ Weather}

A Hobo U30 automatic weather station (Onset Computer Corporation, Bourne, MA, USA) was used to collect daily minimum, maximum, and mean temperatures $\left({ }^{\circ} \mathrm{C}\right)$ and cumulative precipitation. These data were quality checked using Multi-Radar/Multi-Sensor precipitation data (The National Severe Storms Lab, NOAA) as described in Kitchen et al. (2017). Irrigation water applied to eight of the experimental sites as part of normal management practices was treated as natural rainfall in the precipitation equations. Cumulative growing degree-days (GDD) were calculated from the first day of the year where a GDD was accumulated (first-GDD) to the preplant soil sample timing and from the preplant soil sample timing to the V5 corn development stage as described in Clark et al. (2019).

\section{5 | Statistical analysis}

Statistical evaluations were completed across all sites and after soils were grouped into three textural categories (coarse, medium, and fine) at the replication level and two GDD categories (high and low) at the site level because of the influence of soil texture and temperature on PPNT, PSNT, and PMN. Soils were grouped by texture categories following the approach used by Tonitto, David, and Drinkwater (2006) and Tremblay et al. (2012). There were 34 replications that had coarse-textured soils, 88 that had medium-textured soils, and 74 that had fine-textured soils. Sites were also grouped into GDD categories using the classifications from the Nutrient Star TED framework tool (Nutrient Star, 2018), as developed by Van Wart et al. (2013). Experimental sites were classified as high GDD when TED GDD units were $\geq 2,222(4,000$ using ${ }^{\circ} \mathrm{F}$ ) and low GDD when TED GDD units were $<2,222$ $\left(4,000\right.$ using $\left.{ }^{\circ} \mathrm{F}\right)$. Nineteen of the 49 experimental sites were in the low GDD category (Minnesota, North Dakota, Wisconsin, and 2014 Mason City, Iowa) and 30 were in the high GDD category (all other experimental sites in Iowa along with Illinois, Indiana, Missouri, and Nebraska).

All statistical analyses were completed with SAS software version 9.4 (SAS Institute Inc., Cary, NC). The means and standard deviations of RY, PMN, soil properties, and weather measurements were determined using the MEANS procedure. Linear and quadratic regressions were performed using the REG procedure and linear-plateau and quadratic-plateau models using the NLIN procedure. We used these regressions to evaluate the change in predictability of RY when including PMN with PPNT or PSNT (zero-N plots only) and soil available $\mathrm{N}\left(\mathrm{PPNT}_{\mathrm{N}}\right.$ or $\mathrm{PSNT}_{\mathrm{N}}$ using the zero-N plus $\mathrm{N}$-fertilized plots). The CSNC was calculated using the linear-plateau and quadratic-plateau models as the point between the linear or quadratic part of the model and the plateau portion. The linear-plateau model was used because it correctly identified sites as responsive or non-responsive to $\mathrm{N}$ correctly $9-12 \%$ more often than the quadratic-plateau model. The CSNC was the amount of soil available $\mathrm{N}$ (e.g. soil inorganic $\mathrm{N}$ with and without PMN plus $\mathrm{N}$ fertilizer) above which no additional increase in grain yield was predicted. The fit of these models was evaluated by comparing lack of fit F-tests, coefficients of determination (Cerrato \& Blackmer, 1990), and visually assessing the model fit to the data.

We employed a similar approach as used by Bundy et al. (1999) to evaluate the statistical models used to calculate the CSNC and determine whether $\mathrm{N}$ fertilizer should be applied. Briefly, each graph relating RY as a function of soil available $\mathrm{N}$ (e.g. soil inorganic $\mathrm{N}$ with and without PMN plus $\mathrm{N}$ 
fertilizer) was separated into four quadrants with the line dividing the $\mathrm{Y}$-axis at a $\mathrm{RY}$ of $90 \%$ and the $\mathrm{X}$-axis at the CSNC. Values in the upper-left quadrant represented experimental units that were incorrectly categorized as responsive to $\mathrm{N}$ fertilization, resulting in an over-application of $\mathrm{N}$ while values in the lower-right quadrant represented experimental units that were incorrectly categorized as nonresponsive to $\mathrm{N}$ fertilization, resulting in an under-application of $\mathrm{N}$. The percent of sites in these two categories was the total misapplication frequency. Values in the lower-left quadrant represented experimental units that were correctly categorized as responsive to $\mathrm{N}$ and values in the upper-right quadrant represented experimental units that were correctly categorized as nonresponsive to $\mathrm{N}$. The percent of sites in these two categories was the total success frequency. The strength of the relationship between $\mathrm{RY}$ and soil $\mathrm{N}$ measurements as determined by model $\mathrm{R}^{2}$ was also compared.

\section{3 | RESULTS AND DISCUSSION}

Corn grain yield varied across all experimental site-years with a range of $1.4-18.6 \mathrm{Mg} \mathrm{ha}^{-1}$ and a mean of $12.2 \mathrm{Mg}$ $\mathrm{ha}^{-1}$ (Table 1). The mean grain yield varied minimally between coarse- $\left(12.3 \mathrm{Mg} \mathrm{ha}^{-1}\right)$, medium- $\left(12.5 \mathrm{Mg} \mathrm{ha}^{-1}\right)$, and fine-textured soils $\left(11.9 \mathrm{Mg} \mathrm{ha}^{-1}\right)$. Classifying sites into high (12.7 $\left.\mathrm{Mg} \mathrm{ha}^{-1}\right)$ and low (11.4 $\mathrm{Mg} \mathrm{ha}^{-1}$ ) GDD categories resulted in larger mean differences. These differences in yield when evaluating by texture and GDDs may be important because sites with differences in yield potential can alter the CSNC (Fox et al., 1989). Coarse-textured soils generally had the greatest increase in grain yield with added $\mathrm{N}$ fertilizer with a mean increase of $6.6 \mathrm{Mg} \mathrm{ha}^{-1}$ followed by $5.8 \mathrm{Mg} \mathrm{ha}^{-1}$ for medium- and $5.2 \mathrm{Mg} \mathrm{ha}^{-1}$ for fine-textured soils. High GDD sites had a greater increase in mean yield $\left(6.4 \mathrm{Mg} \mathrm{ha}^{-1}\right)$ with added $\mathrm{N}$ fertilizer compared to low GDD sites $(4.5 \mathrm{Mg}$ $\mathrm{ha}^{-1}$ ). Greater grain yield responses to $\mathrm{N}$ fertilizer for some of these categories may be the result of less $\mathrm{N}$ supplied to the corn crop from mineralization (Lory \& Scharf, 2003), as N mineralization potential and soil organic matter concentration are related to soil texture and temperature (Cabrera, Kissel, \& Vigil, 2005; Clark et al., 2019; Kuzyakova, Turyabahika, \& Stahr, 2006). Likewise, our study showed that grain yield response to $\mathrm{N}$ decreased as the mean potential for $\mathrm{N}$ mineralization $(\mathrm{PMN})$ increased among categories within the textural and GDD groupings (Table 1). These results indicate there is a potential benefit to further investigating the use of $\mathrm{PMN}$ as a tool to improve $\mathrm{N}$ need predictions.

\section{1 | Calculating critical soil nitrate content}

When using only the zero-N plots, RY generally increased with soil $\mathrm{N}$ (Figures 1 and 2). The RY was better predicted by PPNT $\left(\mathrm{R}^{2}=0.25-0.26\right)$ or PSNT alone $\left(\mathrm{R}^{2}=0.35-0.43\right)$ than when combined with PMN from any of the three soil sampling methodologies (preplant with $0 \mathrm{~kg} \mathrm{~N} \mathrm{ha}^{-1}$, V5 with $0 \mathrm{~kg} \mathrm{~N} \mathrm{ha}^{-1}$, and V5 with $180 \mathrm{~kg} \mathrm{~N} \mathrm{ha}^{-1}$ applied preplant) $\left(\mathrm{R}^{2}=0.03-0.24\right)$. Only $13 \%$ of the zero-N plots had $\geq 90 \%$ RY; thus, we could not calculate a CSNC for an optimal RY. However, when zero- $\mathrm{N}$ and $\mathrm{N}$ fertilized plots were included, RY increased with soil available $\mathrm{N}\left(\mathrm{PPNT}_{\mathrm{N}}\right.$ and $\left.\mathrm{PSNT}_{\mathrm{N}}\right)$ with and without PMN included until yield plateaued $(\mathrm{P} \leq 0.05)$ (data not shown). The strength of the relationship between RY and soil available $\mathrm{N}$ with and without PMN $\left(\mathrm{R}^{2}=0.19-0.66\right)$ varied by soil grouping and soil $\mathrm{NO}_{3}-\mathrm{N}$ sampling depth (Table 2). A similar conclusion was reported in Northeast Spain (Cela et al., 2013). These results indicate that plantavailable $\mathrm{N}$ early in the season and the amount of $\mathrm{N}$ that may be mineralized during the season for corn after soybean was normally inadequate to obtain optimal yield. This highlights the importance of $\mathrm{N}$ fertilizer application in corn after soybean rotations to obtain optimal yield in the U.S. Midwest.

Generally, the PPNT and PSNT have been most successful when there was little to no $\mathrm{N}$ fertilizer applied, in situations where $\mathrm{N}$ carried over from the previous season, or where diverse cropping systems or recent manure applications led to greater $\mathrm{N}$ mineralization for the current growing season. (Bundy \& Andraski, 1995; Bundy et al., 1999; Magdoff, 1991; Magdoff et al., 1984; Mulvaney, Khan, Hoeft, \& Brown, 2001; Rehm et al., 2002; Schmitt \& Randall, 1994). The low strength of the model $\mathrm{R}^{2}$ between PPNT or PSNT and RY determined from our study support these other findings as the soybean-corn rotations used in this study and in the U.S. Midwest do not have a strong chance of carrying over $\mathrm{N}$ from the previous season. This low $\mathrm{N}$ carry over potential is due to the large $\mathrm{N}$ requirements of corn and substantial potential for residual $\mathrm{N}$ loss with excess precipitation, especially in early spring (Bakhsh et al., 2000; Jokela \& Randall, 1989; Randall, Vetsch, \& Huffman, 2003). Furthermore, our experimental sites had not received any recent manure applications that would have increased their mineralization potential. Therefore, these results indicate that in a primarily corn-soybean rotation, $\mathrm{N}$ fertilized fields need to be included to make sure yields will optimize when calculating a CSNC using soil $\mathrm{N}$ measurements regardless of soil groupings. 
T A B L E 1 Range and mean for various corn grain yield calculations, soil parameters, and weather variables across 49 site-years (All) or partitioned by soil texture (coarse, medium, and fine) or growing degree-day (GDD) categories (high and low)

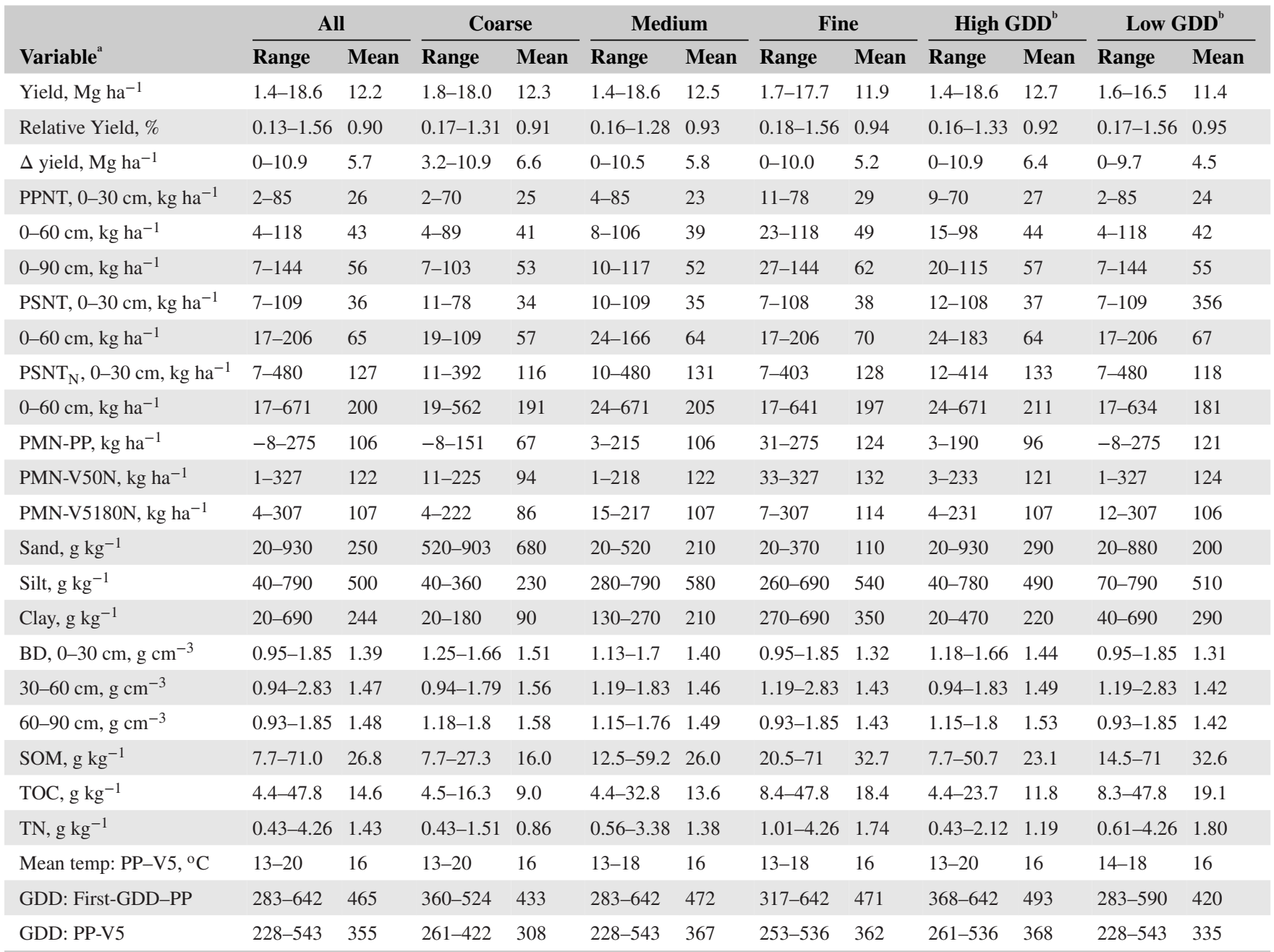

${ }^{a} \Delta$ yield, Yield at economic optimal $\mathrm{N}$ rate minus the yield of the control experimental units as determined by the quadratic-plateau model; PPNT, Preplant nitrate test; PSNT, presidedress nitrate test from $0 \mathrm{~kg} \mathrm{~N}^{-1}$ plots at 0-30 and 0-60 $\mathrm{cm}$ depths; $\mathrm{PSNT}_{\mathrm{N}}$, Presidedress nitrate test from all of the N rate treatments at 0-30 and 0-60 $\mathrm{cm}$ depths; PMN, Anaerobic potentially mineralizable N; PMN-PP, PMN from preplant soil sampling where $0 \mathrm{~kg} \mathrm{~N}$ ha $^{-1}$ was applied; PMN-V50N, PMN from V5 corn development stage where $0 \mathrm{~kg} \mathrm{~N}^{-1}$ was applied; PMN-V5180N, PMN from V5 corn development stage where $180 \mathrm{~kg} \mathrm{~N}^{-1}$ was applied preplant; BD, Bulk density; SOM, Soil organic matter; TOC, Total organic C; TN, Total N; Temp., Temperature; First-GDD, First day of the calendar year where a GDD is accumulated; PP, Preplant soil sample timing; V5, Five leaf corn development stage.

${ }^{\mathrm{b}} \mathrm{High}$ GDD includes sites where typical number of GDD is $>2,222$ and Low GDD includes sites where typical number of GDD is $<2,222$.

\subsection{Soil $\mathrm{NO}_{3}-\mathrm{N}$ sampling depth}

For the $\mathrm{PPNT}_{\mathrm{N}}$ alone or combined with PMN, sampling soil $\mathrm{NO}_{3}-\mathrm{N}$ beyond $30 \mathrm{~cm}$ in low GDD sites improved $\mathrm{RY}$ predictability by an $\mathrm{R}^{2}$ of as much as 0.07 , but for other categories increases in $\mathrm{R}^{2}$ were $<0.03$ (Table 2). This result likely occurred because of greater soil $\mathrm{NO}_{3}-\mathrm{N}$ deeper in the soil profile for low GDD sites compared to other soil categories (Table 1). However, the improved RY predictability with deeper soil samples still did not substantially reduce $(\leq 2 \%)$ the misapplication frequency in any category (Table 2). Others also reported that RY predictability improvements from increasing PPNT sampling depths beyond $30 \mathrm{~cm}$ were insufficient to justify the increased time and cost of obtaining the deeper soil samples (Binford et al., 1992; Bundy \& Andraski, 1995; Cela et al., 2013). In contrast to the minimal reduction in over-application frequency we observed $(\leq 2 \%)$, Bundy et al. (1999) reported a greater (8\%, on average) reduction in $\mathrm{N}$ over-application frequency with deeper sampling. Our results highlight that a shallow $0-30 \mathrm{~cm}$ sampling depth is sufficient for the $\mathrm{PPNT}_{\mathrm{N}}$, and the only exception may be in soils that have large amounts of $\mathrm{NO}_{3}-\mathrm{N}$ in the deeper soil depths, as pointed out by Bundy et al. (1999). For the $\mathrm{PSNT}_{\mathrm{N}}$ alone or combined with PMN, increasing soil $\mathrm{NO}_{3}-\mathrm{N}$ sampling depth from 30 to $60 \mathrm{~cm}$ across all soil categories improved RY predictability by an $\mathrm{R}^{2}$ of as much as 0.20 . Other research has reported that the cost of deeper soil sampling is normally only compensated by improvements in explained variability 
TA B L E 2 Model $\mathrm{R}^{2}$ and misapplication type and frequency from linear-plateau regressions using different combinations of soil available $\mathrm{N}$ from various soil sampling depths with and without anaerobic potentially mineralizable $\mathrm{N}$ (PMN) from three sampling methodologies across 49 site-years or partitioned by soil texture (coarse, medium, and fine) or growing degree-day (GDD) categories (high and low)

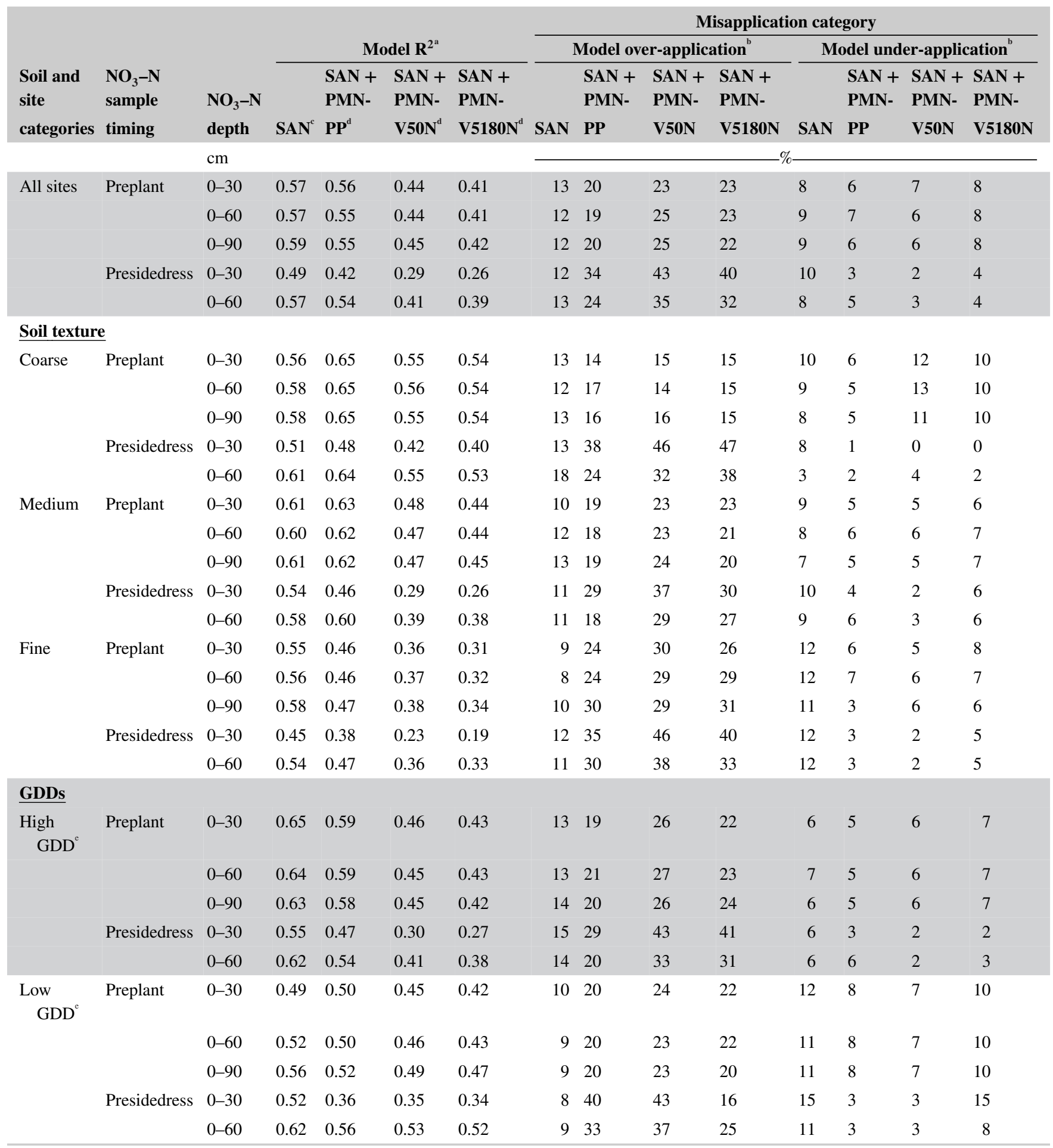

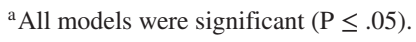

${ }^{\mathrm{b}}$ Over-application of $\mathrm{N}$ from incorrect categorization as responsive; Under-application of $\mathrm{N}$ from incorrect categorization as nonresponsive.

${ }^{\mathrm{c}} \mathrm{SAN}$, Soil available $\mathrm{N}$ was calculated for the preplant nitrate test timing as soil $\mathrm{NO}_{3}-\mathrm{N}$ plus $\mathrm{N}$ fertilizer rate applied to each plot [PPNT $+\mathrm{N}$ rate from 0-315 $\mathrm{kg}^{-1}$ $\left.\left(\mathrm{PPNT}_{\mathrm{N}}\right)\right]$ and for the presidedress nitrate test timing as soil $\mathrm{NO}_{3}-\mathrm{N}$ from the zero- $\mathrm{N}$ and $\mathrm{N}$ fertilized $\left(45-315 \mathrm{~kg} \mathrm{ha}^{-1}\right)$ plots $\left(\mathrm{PSNT}_{\mathrm{N}}\right)$

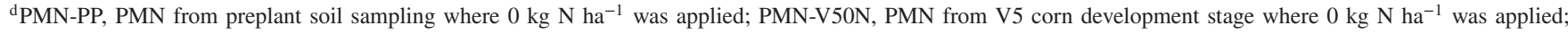
PMN-V5180N, PMN from V5 corn development stage where $180 \mathrm{~kg} \mathrm{~N} \mathrm{ha}^{-1}$ was applied preplant.

${ }^{\mathrm{e}} \mathrm{High}$ GDD, sites where typical number of GDDs is $>2,222$; Low GDD, sites where typical number of GDDs is $<2,222$. 


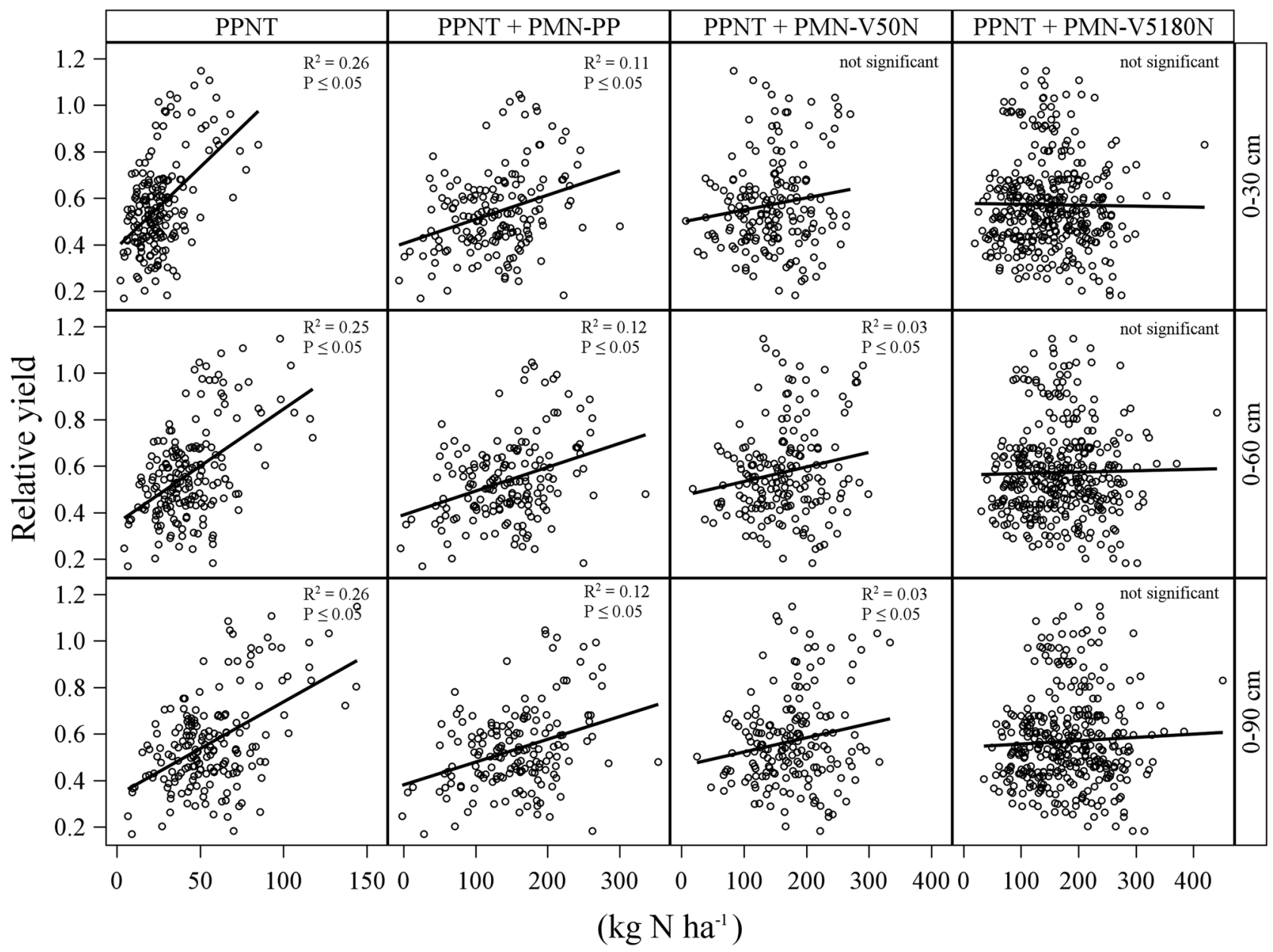

F I G U R E 1 In $0 \mathrm{~kg} \mathrm{~N}$ ha $^{-1}$ plots across 49 site-years, relationship between relative corn yield and soil $\mathrm{NO}_{3}-\mathrm{N}$ content before planting and fertilization at three depths (PPNT) and PPNT combined with anaerobic potentially mineralizable N (PMN) from three sampling methodologies (soil sampled before planting and $\mathrm{N}$ fertilization [PPNT + PMN-PP], soil sampled at the V5 corn development stage where 0 [PPNT + PMN-V50N] or $180 \mathrm{~kg} \mathrm{~N} \mathrm{ha}^{-1}$ [PPNT + PMN-V5180N] was applied at planting)

of RY in permeable soils that have a greater chance of $\mathrm{N}$ leaching past the 30-cm depth such as coarse-textures soils (Magdoff et al., 1984; Vinten, Vivian, Wright, \& Howard, 1994). However, RY predictability using PSNT from $0-60 \mathrm{~cm}$ compared to $0-30 \mathrm{~cm}$ soil samples in our fine-textured soils improved similarly or more (0.09-0.14 improvement in $\left.\mathrm{R}^{2}\right)$ than that in the coarse-textured soils (0.10-0.16 improvement in $\mathrm{R}^{2}$ ). These results indicate that less permeable soils such as fine-textured soils can benefit from deeper PSNT sampling similarly to coarse-textured soils.

\section{3 | Including PMN with PPNT $_{N}$ to improve $\mathrm{N}$ management}

The $\mathrm{PPNT}_{\mathrm{N}}$ alone across soil categories accounted for $49-65 \%$ of the variability in RY (Table 2). Partitioning soils into texture categories marginally improved RY predictability
$(<0.04)$ by PPNT $_{\mathrm{N}}$ alone only in medium-textured soils and altered the total misapplication frequency $\leq 5 \%$. Across soil texture categories, including PMN with $\mathrm{PPNT}_{\mathrm{N}}$ improved $\mathrm{RY}$ predictability by an $\mathrm{R}^{2}$ between $0.07-0.10$, but only when using PMN from preplant and in coarse- and mediumtextured soils. In fine-textured soils, including PMN, with $\mathrm{PPNT}_{\mathrm{N}}$ regardless of sampling methodology substantially reduced RY predictability by an $\mathrm{R}^{2}$ between $0.08-0.24$ and increased the total misapplication frequency (Table 2). The PMN test may have underestimated mineralizable- $\mathrm{N}$ in fine-textured soils because the greater organic matter and clay content of these soils (Table 1) produce more $\mathrm{NH}_{4}-\mathrm{N}$ during incubations, resulting in suppressed mineralization and more $\mathrm{NH}_{4}-\mathrm{N}$ fixed to clay surfaces (Russell, Dunn, Batten, Williams, \& Angus, 2006). This underestimation of PMN is likely the reason for the weaker relationships with RY in fine-textured soils. Others observed improvements in yield predictability when including PMN from preplant with 


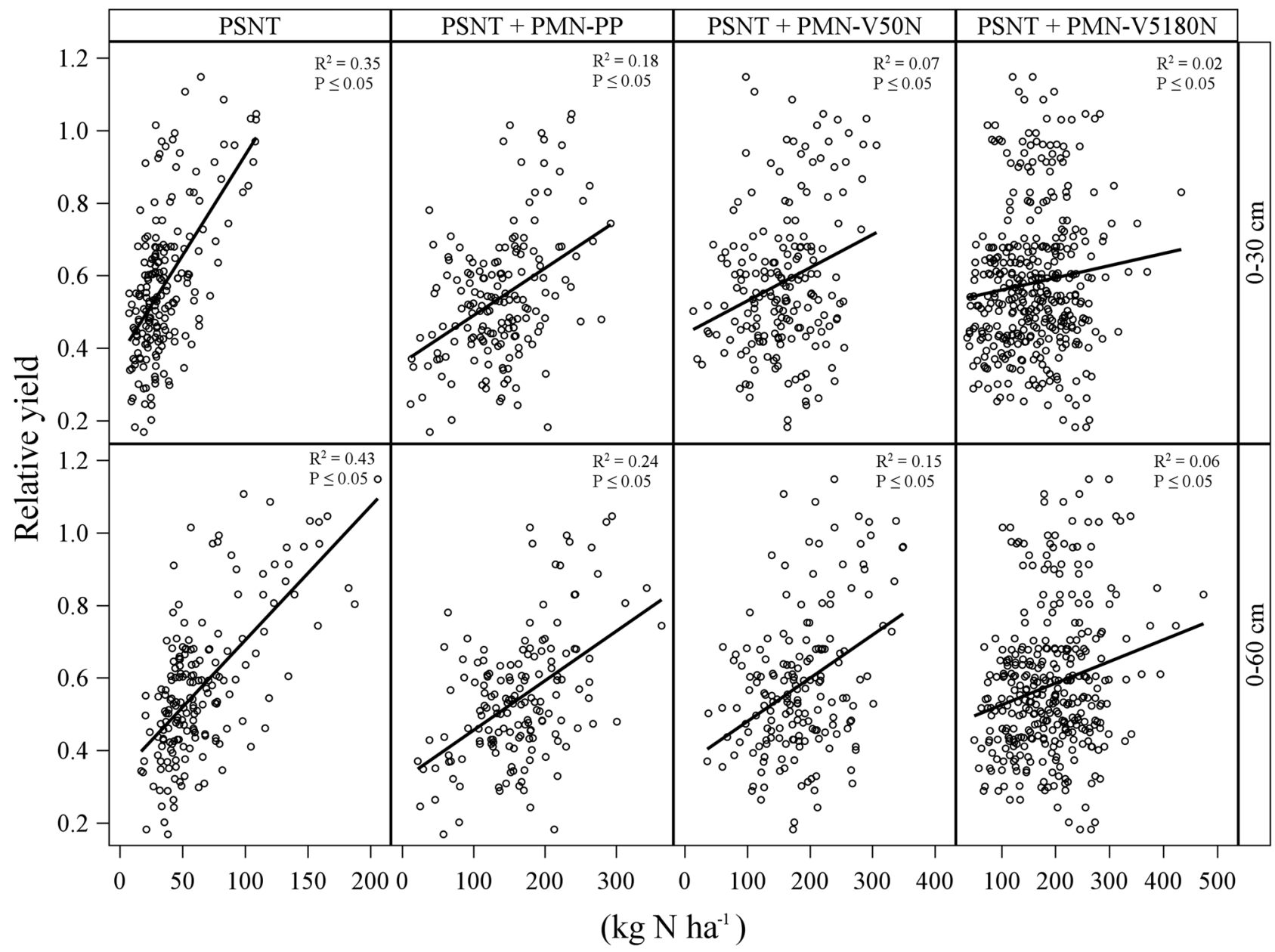

F I G U R E 2 In $0 \mathrm{~kg} \mathrm{~N} \mathrm{ha}^{-1}$ plots across 49 site-years, relationship between relative corn yield and soil $\mathrm{NO}_{3}-\mathrm{N}$ content at the V5 \pm 1 corn development stage at two depths alone (PSNT) and PSNT combined with anaerobic potentially mineralizable N (PMN) from three sampling methodologies (soil sampled before planting and N fertilization [PSNT + PMN-PP], soil sampled at the V5 corn development stage where 0 [PSNT $+\mathrm{PMN}-\mathrm{V} 50 \mathrm{~N}]$ or $180 \mathrm{~kg} \mathrm{~N} \mathrm{ha}^{-1}$ [PSNT + PMN-V5180N] was applied at planting)

PPNT when soils with similar soil textures, topographies, and climate conditions were evaluated together (Nyiraneza, N'Dayegamiye, Chantigny, \& Laverdière, 2009; Orcellet et al., 2017; Reussi Calvo, Rozas, Echeverría, \& Berardo, 2013; Sainz Rozas et al., 2008). Our findings and these of others indicate that soil texture is an important variable to consider when using soil mineralization tests. Further, our results show that the improved predictability of $\mathrm{N}$ fertilizer needs by including PMN is soil texture dependent and for some soils including PMN will not improve $\mathrm{N}$ management.

Partitioning soils into GDD categories improved RY predictability by an $\mathrm{R}^{2}$ between $0.04-0.08$ by $\mathrm{PPNT}_{\mathrm{N}}$ alone for high GDD sites but reduced it by an $\mathrm{R}^{2}$ between 0.02 0.07 for low GDD sites (Table 2). The total misapplication frequency (20-23\%) remained similar to when all sites were evaluated together even with the changes in RY predictability when grouping sites by GDDs. The lack of change in total misapplication frequency was because the reduction in one misapplication category (under- or over-application) was offset by the increase in the other category. For both GDD categories, including PMN from any of the three sampling methodologies with $\mathrm{PPNT}_{\mathrm{N}}$ did not improve RY predictability or reduce any of the misapplication frequency categories, similar to the results from fine-textured soils. This lack of improvement in RY predictability when PMN was included with $\mathrm{PPNT}_{\mathrm{N}}$ may be because the GDD categories did not separate out the influence of greater clay and soil organic matter content on PMN as discussed earlier for the analysis of soils partitioned by texture.

\subsection{Including PMN with PSNT $_{\mathrm{N}}$ to improve N management}

The $\operatorname{PSNT}_{\mathrm{N}}$ alone across soil categories accounted for $45-62 \%$ of the variability in RY (Table 2). Partitioning soils 
into texture categories improved RY predictability by $\mathrm{PSNT}_{\mathrm{N}}$ alone $0.02-0.05$ for coarse- and medium-textured soils and reduced RY predictability by an $\mathrm{R}^{2}$ between $0.03-0.05$ for fine-textured soils (Table 2). Only a minimal improvement in $\mathrm{RY}$ predictability $\left(\leq 0.03\right.$ increase in $\left.\mathrm{R}^{2}\right)$ resulted from

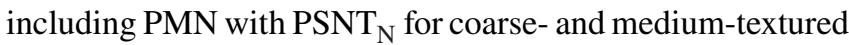
soils but only when using PMN from the preplant sampling and using PSNT $_{\mathrm{N}}$ at the $0-60 \mathrm{~cm}$ soil sampling depth. The reduced improvement in RY predictability by including PMN with $\mathrm{PSNT}_{\mathrm{N}}$ compared with $\mathrm{PPNT}_{\mathrm{N}}$ was likely because the $\mathrm{PSNT}_{\mathrm{N}}$ accounts for the net $\mathrm{N}$ mineralization potential of the soil up to the V5 development stage, as discussed earlier (Magdoff et al., 1984). Whereas, the $\mathrm{PPNT}_{\mathrm{N}}$ accounted for little to no net $\mathrm{N}$ mineralization potential because it was performed early in the spring before substantial $\mathrm{N}$ mineralization and $\mathrm{N}$ loss processes occurred. The improvements in RY predictability with PMN from preplant combined with $\mathrm{PSNT}_{\mathrm{N}}$ for coarse- and medium-textured soils resulted in an increase in the over-application frequency similar to including PMN from preplant with $\mathrm{PPNT}_{\mathrm{N}}$ (Table 2). No further improvement in RY predictability or reduction in misapplication frequency resulted from including PMN from either of the V5 $\mathrm{N}$ rates for coarse- and medium-textured soils or the inclusion of PMN from any sampling methodology for fine-textured soils.

Partitioning sites by GDD also improved RY predictability using $\operatorname{PSNT}_{N}$ alone; however, the improvements in predictability did not reduce the total misapplication frequency, which was similar to using $\mathrm{PPNT}_{\mathrm{N}}$ alone (Table 2). The total misapplication frequency did not change because when one of the misapplication categories increased (underor over-application), the other misapplication frequency increased similarly. Including PMN from any sampling methodology with $\mathrm{PSNT}_{\mathrm{N}}$ did not improve the RY predictability or reduce any of the misapplication frequencies for either GDD category, similar to evaluating fine-textured soils alone. Therefore, including PMN as a mineralization estimate with $\mathrm{PSNT}_{\mathrm{N}}$ was not an effective method to improve $\mathrm{N}$ management when soils were partitioned by GDDs alone.

Overall, including the PMN test as an estimate of N mineralization with $\mathrm{PPNT}_{\mathrm{N}}$ or $\mathrm{PSNT}_{\mathrm{N}}$ was not able to improve RY predictability substantially or minimize rates of $\mathrm{N}$ fertilizer over- and under-fertilization. There are several reasons this may have occurred. First, Bundy and Meisinger (1994) point out that the PMN test is done under anaerobic conditions where microbial respiration is much slower than aerobic conditions, which may result in underestimating actual $\mathrm{N}$ mineralization. Second, since anaerobic conditions kills aerobic organisms, the PMN test may be mainly measuring the death and lysing of $\mathrm{N}$ from aerobic microorganisms and not mineralizable N. However, the PMN test was evaluated in this study because it was reported in other studies that the use of the PMN test improved N management (Williams et al., 2007; Nyiraneza et al., 2009; Orcellet et al., 2017; Reussi Calvo et al., 2013; Sainz Rozas et al., 2008). In addition, we measured PMN from the $0-30 \mathrm{~cm}$ soil depth; however mineralization occurs below $30 \mathrm{~cm}$ and also including mineralization estimates from deeper soil depths may improve relationships between $\mathrm{N}$ mineralization estimates and RY. Future studies could evaluate the effect of including other N mineralization estimates such as the anaerobic mineralization test from surface and subsurface soils with PPNT or PSNT on RY predictability.

\section{5 | Influence of soil texture and growing degree-days on critical soil nitrate content}

The CSNC calculated using soil available $\mathrm{N}$ (including both zero- $\mathrm{N}$ and $\mathrm{N}$ fertilized plots) increased with deeper soil $\mathrm{NO}_{3}-\mathrm{N}$ sampling depths and when including PMN for all soil categories (Table 3). For the PPNT $_{\mathrm{N}}$ model, the CSNC values across soil categories ranged between $122-175 \mathrm{~kg}$ $\mathrm{ha}^{-1}$ (31-39 $\mathrm{mg} \mathrm{kg}^{-1}$ ) for the top $30 \mathrm{~cm}, 143-190 \mathrm{~kg} \mathrm{ha}^{-1}$ $\left(17-21 \mathrm{mg} \mathrm{kg}^{-1}\right)$ for the top $60 \mathrm{~cm}$, and $157-207 \mathrm{~kg} \mathrm{ha}^{-1}$ (13-15 mg kg${ }^{-1}$ ) for the top $90 \mathrm{~cm}$. These CSNC values from PPNT $_{\mathrm{N}}$ models were normally lower than those found by Cela et al. (2013) where the CSNC for the 0-30-cm depth was $172-243 \mathrm{~kg} \mathrm{~N} \mathrm{ha}^{-1}$ and for the 0-90-cm depth CSNC was $208-302 \mathrm{~kg} \mathrm{~N} \mathrm{ha}^{-1}$. These greater CSNC values from the Cela et al. (2013) study may be due to the greater mean PPNT values of their study sites (0-30 cm: $60-69 \mathrm{~kg} \mathrm{~N} \mathrm{ha}^{-1}$; 0-90 cm: $\left.119-180 \mathrm{~kg} \mathrm{~N} \mathrm{ha}^{-1}\right)$ compared to ours $(0-30 \mathrm{~cm}$ : 23-29 kg N ha ${ }^{-1}$; 0-90 cm: 52-62 $\mathrm{kg} \mathrm{N} \mathrm{ha}^{-1}$ ). Our lower PPNT values were likely the result of lower $\mathrm{N}$ carryover potential in our study region as discussed earlier.

There were distinct differences between CSNC values within soil texture and GDD groupings for the $\mathrm{PPNT}_{\mathrm{N}}$ model (Table 3). Across sampling depths, the CSNC values using $\mathrm{PPNT}_{\mathrm{N}}$ alone were $175-207 \mathrm{~kg} \mathrm{ha}^{-1}$ for coarse-textured soils, $145-183 \mathrm{~kg} \mathrm{ha}^{-1}$ for medium-textured soils, and $128-178 \mathrm{~kg}$ $\mathrm{ha}^{-1}$ for fine-textured soils. The decrease in CSNC with finer textures likely occurred because mineralization supplied more $\mathrm{N}$, as indicated by greater PMN for fine-textured soils (Table 1). For the coarse- and medium-textured soils where including PMN with $\mathrm{PPNT}_{\mathrm{N}}$ improved RY predictability, the CSNC from medium-textured soils (287-322 $\mathrm{kg} \mathrm{ha}^{-1}$ ) became greater than that of coarse-textured soils (256$295 \mathrm{~kg} \mathrm{ha}^{-1}$ ) because PMN from preplant soil was greater for medium-textured soils (Table 1).

The CSNCs using soil $\mathrm{NO}_{3}-\mathrm{N}$ alone were $171-207 \mathrm{~kg}$ $\mathrm{ha}^{-1}$ for high GDD sites and 122-157 kg ha ${ }^{-1}$ for low GDD sites (Table 3). Likely, the lower temperatures and GDDs (Table 1) in the low GDD sites limited $\mathrm{N}$ mineralization early in the season and reduced the PPNT and CSNC. 
T A B L E 3 Critical soil nitrate content (CSNC) from linear-plateau regressions using different combinations of soil available $\mathrm{N}$ from various soil sampling depths with and without anaerobic potentially mineralizable $\mathrm{N}$ (PMN) from three sampling methodologies across 49 site-years or partitioned by soil texture (coarse, medium, and fine) or growing degree-day (GDD) categories (high and low)

\begin{tabular}{|c|c|c|c|c|c|c|}
\hline \multirow[b]{2}{*}{$\begin{array}{l}\text { Soil and site } \\
\text { categories }\end{array}$} & \multirow[b]{2}{*}{$\begin{array}{l}\mathrm{NO}_{3}-\mathrm{N} \text { sample } \\
\text { timing }\end{array}$} & \multirow[b]{2}{*}{$\begin{array}{l}\mathrm{NO}_{3}-\mathrm{N} \\
\text { depth }\end{array}$} & \multicolumn{4}{|c|}{ Model parameters $^{\mathrm{a}}$} \\
\hline & & & $\mathbf{S A N} \mathbf{N}^{\mathrm{b}}$ & $\begin{array}{l}\text { SAN + } \\
\text { PMN-PP }^{c}\end{array}$ & $\begin{array}{l}\text { SAN + } \\
\text { PMN-V50N }\end{array}$ & $\begin{array}{l}\text { SAN + } \\
\text { PMN-V5180N }^{\mathrm{c}}\end{array}$ \\
\hline \multirow[t]{4}{*}{ All } & \multirow[t]{2}{*}{ Preplant } & $0-30$ & 160 & 297 & 323 & 303 \\
\hline & & $0-60$ & 173 & 314 & 345 & 317 \\
\hline & Presidedress & $0-30$ & 88 & 287 & 324 & 294 \\
\hline & & $0-60$ & 157 & 314 & 377 & 344 \\
\hline \multicolumn{7}{|l|}{$\underline{\text { Soil texture }}$} \\
\hline \multirow[t]{2}{*}{ Coarse } & \multirow[t]{2}{*}{ Preplant } & $0-30$ & 175 & 256 & 267 & 264 \\
\hline & & $0-60$ & 190 & 282 & 276 & 280 \\
\hline \multirow[t]{5}{*}{ Medium } & \multirow[t]{3}{*}{ Preplant } & $0-30$ & 145 & 287 & 322 & 301 \\
\hline & & $0-60$ & 167 & 306 & 335 & 307 \\
\hline & & $0-90$ & 183 & 322 & 350 & 315 \\
\hline & \multirow[t]{2}{*}{ Presidedress } & $0-30$ & 92 & 265 & 306 & 257 \\
\hline & & $0-60$ & 150 & 289 & 357 & 319 \\
\hline \multirow[t]{3}{*}{ Fine } & \multirow[t]{3}{*}{ Preplant } & $0-30$ & 128 & 337 & 360 & 321 \\
\hline & & $0-60$ & 149 & 350 & 371 & 350 \\
\hline & & $0-90$ & 178 & 402 & 386 & 379 \\
\hline \multirow{2}{*}{ High GDD $^{\mathrm{d}}$} & \multirow[t]{2}{*}{ Presidedress } & $0-30$ & 118 & 277 & 331 & 319 \\
\hline & & $0-60$ & 188 & 312 & 396 & 381 \\
\hline \multirow[t]{5}{*}{ Low GDD ${ }^{d}$} & \multirow[t]{3}{*}{ Preplant } & $0-30$ & 122 & 294 & 312 & 276 \\
\hline & & $0-60$ & 143 & 310 & 324 & 294 \\
\hline & & $0-90$ & 157 & 322 & 336 & 301 \\
\hline & \multirow[t]{2}{*}{ Presidedress } & $0-30$ & 60 & 297 & 295 & 169 \\
\hline & & $0-60$ & 113 & 336 & 321 & 260 \\
\hline
\end{tabular}

${ }^{a}$ All models were significant $(\mathrm{P} \leq 0.05)$.

${ }^{\mathrm{b}} \mathrm{S} A \mathrm{~N}$, Soil available $\mathrm{N}$ was calculated for the preplant nitrate test timing as soil $\mathrm{NO}_{3}-\mathrm{N}$ plus $\mathrm{N}$ fertilizer rate applied to each plot [PPNT $+\mathrm{N}$ rate from 0-315 kg ha ${ }^{-1}$

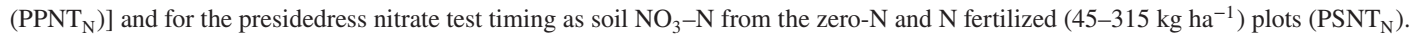

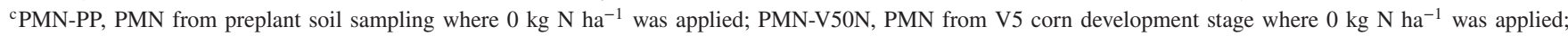
PMN-V5180N, PMN from V5 corn development stage where $180 \mathrm{~kg} \mathrm{~N} \mathrm{ha}^{-1}$ was applied preplant.

${ }^{\mathrm{d}}$ High GDD, sites where typical number of GDDs is $>2,222$; Low GDD, sites where typical number of GDDs is $<2,222$.

For $\mathrm{PSNT}_{\mathrm{N}}$ alone models, the range of CSNC was generally less than that of the PPNT $_{\mathrm{N}}$ alone model and ranged between $60-118 \mathrm{~kg} \mathrm{ha}^{-1}\left(15-27 \mathrm{mg} \mathrm{kg}^{-1}\right)$ for the top $30 \mathrm{~cm}$ and $113-193 \mathrm{~kg} \mathrm{ha}^{-1}\left(14-21 \mathrm{mg} \mathrm{kg}^{-1}\right)$ for the top $60 \mathrm{~cm}$ (Table 3). These CSNC values were similar to other studies where the CSNC was between $16-33 \mathrm{mg} \mathrm{kg}^{-1}$ for the $0-30$-cm depth and between $12-19 \mathrm{mg} \mathrm{kg}^{-1}$ for the $0-60 \mathrm{~cm}$ depth (Barbieri et al., 2008; Binford et al., 1992; Brouder \& Mengel, 2003; Bundy \& Andraski, 1995; Bundy et al., 1999; Cela et al., 2013; Evanylo \& Alley, 1997; Ma \& Wu, 2008; 
Magdoff, Jokela, Fox, \& Griffin, 1990; Meisinger, Bandel, Angle, O'Keefe, \& Reynolds, 1992; Randall, Vetsch, \& Huffman, 1996; Sainz Rozas et al., 2000; Schmitt \& Randall, 1994; Zebarth \& Paul, 1997). This similar range in CSNC across those studies and ours (encompassing nearly 30 years) indicates that CSNC values are robust because they have not changed substantially despite changes in hybrids, grain yield level, and tillage and other agronomic practices.

There were also distinct differences between CSNC values within soil texture and GDD groupings for the $\mathrm{PSNT}_{\mathrm{N}}$ alone model (Table 3). The CSNC from PSNT ${ }_{N}$ for both coarse- (88 and $157 \mathrm{~kg} \mathrm{ha}^{-1}$ ) and medium-textured soils (92 and $150 \mathrm{~kg}$ $\mathrm{ha}^{-1}$ ) were similar while fine-textured soils were still in a lower range (81 and $135 \mathrm{~kg} \mathrm{ha}^{-1}$ ), which is opposite of what we observed for the PPNT $_{N}$ model. The CSNC for high GDD sites were greater $\left(118\right.$ and $\left.188 \mathrm{~kg} \mathrm{ha}^{-1}\right)$ than the low GDD sites $\left(60\right.$ and $\left.113 \mathrm{~kg} \mathrm{ha}^{-1}\right)$. The lower temperatures for the low GDD sites before the time of $\mathrm{PSNT}_{\mathrm{N}}$ sampling (Table 1) likely decreased the quantity of $\mathrm{N}$ mineralized (Ma \& Wu, 2008) and reduced $\mathrm{PSNT}_{\mathrm{N}}$ and the subsequent CSNC. Others also reported similar results (Andraski \& Bundy, 2002; N'Dayegamiye et al., 2015; Sainz Rozas et al., 2008). These results indicated that CSNC was influenced by soil texture and temperature and that these variables should be considered when determining and using CSNC values to manage $\mathrm{N}$ fertilizer needs.

\section{4 | CONCLUSIONS}

Using only the zero-N plots, RY was not $>90 \%$ in enough of them for CSNC to be calculated using only PPNT and PSNT. However, using the zero- $\mathrm{N}$ and $\mathrm{N}$ fertilized plots $\left(\mathrm{PPNT}_{\mathrm{N}}\right.$ and $\mathrm{PSNT}_{\mathrm{N}}$ ) resulted in sufficient plots yielding greater than $90 \% \mathrm{RY}$ and enabled CSNC to be calculated. In future studies, other cropping rotations besides the primarily cornsoybean rotations used in this study and other management practices that increase $\mathrm{N}$ mineralization potential should be included to more completely evaluate mineralization potential and calculate CSNC using PPNT and PSNT from only zero-N plots.

For $\mathrm{PPNT}_{\mathrm{N}}$ and $\mathrm{PSNT}_{\mathrm{N}}$ based models, partitioning soils into textural or GDD categories improved RY predictability marginally for some categories but did not reduce the total misapplication frequency (under- plus over-application of $\mathrm{N})$. The inclusion of PMN with $\mathrm{PPNT}_{\mathrm{N}}$ or $\mathrm{PSNT}_{\mathrm{N}}$ only improved RY predictability for coarse- and medium-textured soils and only with PMN from preplant. However, including PMN with $\mathrm{PPNT}_{\mathrm{N}}$ or $\mathrm{PSNT}_{\mathrm{N}}$ did not substantially reduce over-application frequencies and only minimally reduced under-application frequencies. Therefore, this study demonstrated that including PMN with $\mathrm{PPNT}_{\mathrm{N}}$ or $\mathrm{PSNT}_{\mathrm{N}}$ to account for $\mathrm{N}$ mineralization had little utility to improve $\mathrm{N}$ management regardless of soil $\mathrm{NO}_{3}-\mathrm{N}$ sampling depth, $\mathrm{PMN}$ sampling methodology, and soil categorization evaluated. However, this study showed that CSNC varied extensively within soil texture and GDD categories, indicating that these parameters may have potential to improve CSNC calculations to reduce over- and under-applications of $\mathrm{N}$ fertilizer.

\section{ACKNOWLEDGMENTS}

We would like to thank DuPont Pioneer for funding this research. The authors thank the supporting scientists [Matt Yost; Dan Barker (IA); Lakesh Sharma, Amitava Chatterjee, and Norm Cattanach (ND); Todd Andraski (WI); and Tim Hart (DuPont Pioneer)], graduate students [Curtis Ransom and Gregory Bean (MO), Christopher Bandura (WI), and Matt Shafer (IN)], field technicians [Matt Volkmann (MO); Jason Niekamp and Joshua Vonk (IL); Glen Slater (NE); Andrew Scobbie, Thor Sellie, Nicholas Severson, Darby Martin, and Erik Joerres (MN)], and cooperating farmers and research farm personnel for their help in completing this project. Mention of trade names or commercial products in this publication is solely for the purpose of providing information and does not imply recommendation or endorsement by the affiliated Universities or the U.S. Department of Agriculture.

\section{ORCID}

Jason D. Clark (1) https://orcid.org/0000-0001-7793-6411

Kristen S. Veum (1D https://orcid.org/0000-0002-6492-913X

James J. Camberato (D)

https://orcid.org/0000-0002-6677-854X

David W. Franzen (D) https://orcid.org/0000-0003-4862-8086

Daniel E. Kaiser (iD https://orcid.org/0000-0002-8478-701X

Newell R. Kitchen (D) https://orcid.org/0000-0003-2268-9016

John E. Sawyer (D) https://orcid.org/0000-0003-4080-9616

\section{REFERENCES}

Andraski, T. W., \& Bundy, L. G. (2002). Using the presidedress soil nitrate test and organic nitrogen crediting to improve corn nitrogen recommendations. Agronomy Journal, 94, 1411-1418.

Bakhsh, A., Kanwar, R. S., Karlen, D. L., Cambardella, C. A., Colvin, T. S., Moorman, T. B., \& Bailey, T. B. (2000). Tillage and nitrogen management effects on crop yield and residual soil nitrate. Transactions of the ASAE, 43, 1589-1595.

Barbieri, P. A., Echeverría, H. E., \& Saínz Rozas, H. R. (2008). Presidedress soil nitrogen test for no-tillage maize at different row spacing. Agronomy Journal, 100, 1101-1105. https://doi.org/10.2134/ agronj2007.0130

Bast, L. E., Mullen, R. W., Eckert, D. J., \& Thomison, P. R. (2012). Evaluation of the pre-sidedress soil nitrate test in Ohio. Crop Management. https://doi.org/10.1094/CM-2012-0409-01-RS

Binford, G. D., Blackmer, A. M., \& Cerrato, M. E. (1992). Relationships between corn yields and soil nitrate in late spring. Agronomy Journal, $84,53-59$. 
Broadbent, F. E., \& Hauck, R. D. (1984). Plant use of soil nitrogen. In R. D. Haulk (Ed.), Nitrogen in crop production (pp. 171-182). Madison, WI: ASA, CSSA, and SSSA.

Brouder, S. M., \& Mengel, D. B. (2003). The presideress soil nitrate test for improving N management in corn. AY-314-2. West Lafayette, IN: Purdue Univ. Coop. Ext. Service.

Bundy, L. G., \& Andraski, T. W. (1995). Soil yield potential effects on performance of soil nitrate tests. Journal of Production Agriculture, $8,561-568$.

Bundy, L. G., Kelling, K. A., Schulte, E. E., Combs, S., Wolkowski, R. P., \& Sturgul, S. J. (1994). Nutrient management: Practices for Wisconsin corn production and water quality protection. Ext. Publ. A3557. Madison, WI: Wisconsin Coop. Extension.

Bundy, L. G., \& Meisinger, J. J. (1994). Nitrogen availability indices. In R. W. Weaver (Ed.), Methods of soil analysis: Biochemical and microbial properties (pp. 951-984). SSSA Monogr. 5. Madison, WI: SSSA.

Bundy, L. G., Walters, D. T., \& Olness, A. E. (1999). Evaluation of soil nitrate tests for predicting corn nitrogen response in the North Central Region. Publ. No. 342. Madison, WI: Wisconsin Coop. Extension.

Cabrera, M. L., Kissel, D. E., \& Vigil, M. F. (2005). Nitrogen mineralization from organic residues: Research opportunities. Journal of Environmental Quality, 34, 75-79. https://doi.org/10.2134/jeq2005. 0075

Cavigelli, M. A., Del Grosso, S. J., Liebig, M. A., Snyder, C. S., Fixen, P. E., Venterea, R. T., ... Watts, D. B. (2012). US agricultural nitrous oxide emissions: Context, status, and trends. Frontiers in Ecology and the Environment, 10, 537-546. https://doi.org/10.1890/120054

Cela, S., Berenguer, P., Ballesta, A., Santiveri, F., \& Lloveras, J. (2013). Prediction of relative corn yield with soil-nitrate tests under irrigated Mediterranean conditions. Agronomy Journal, 105, 1101. https://doi. org/10.2134/agronj2012.0473

Cerrato, M. E., \& Blackmer, A. M. (1990). Comparison of models for describing corn yield response to nitrogen fertilizer. Agronomy Journal, 82, 138-143. https://doi.org/10.2134/agronj1990. 00021962008200010030x

Clark, J. D., Veum, K. S., Fernández, F. G., Camberato, J. J., Carter, P. R., Ferguson, R. B., ... Shanahan, J. F. (2019). United States Midwest soil and weather conditions influence anaerobic potentially mineralizable nitrogen. Soil Science Society of America Journal, 83, 11371147. https://doi.org/10.2136/sssaj2019.02.0047

Clark, J. D., Veum, K. S., Fernández, F. G., Kitchen, N. R., Camberato, J. J., Carter, P. R., ... Shanahan, J. F. (2020). Soil sample timing, nitrogen fertilization, and incubation length influence anaerobic potentially mineralizable nitrogen. Soil Science Society of America Journal. https://doi.org/10.1002/saj2.20050

Culman, S. W., Snapp, S. S., Green, J. M., \& Gentry, L. E. (2013). Short- and long-term labile soil carbon and nitrogen dynamics reflect management and predict corn agronomic performance. Agronomy Journal, 105, 493-502. https://doi.org/10.2134/agronj2012.0382

Dinnes, D. L., Karlen, D. L., Jaynes, D. B., Kaspar, T. C., Hatfield, J. L., Colvin, T. S., \& Cambardella, C. A. (2002). Nitrogen management strategies to reduce nitrate leaching in tile-drained Midwestern soils. Agronomy Journal, 94, 153-171. https://doi.org/10.2134/ agronj2002.0153

Evanylo, G. K., \& Alley, M. M. (1997). Presidedress soil nitrogen test for corn in Virginia. Communications in Soil Science and Plant Analysis, 28, 1285-1301. https://doi.org/10.1080/00103629709369874
Fernández, F. G., Nafziger, E. D., Ebelhar, S. A., \& Hoeft, R. G. (2009). Managing nitrogen. In E. D. Nafziger (Ed.), Illinois agronomy handbook (24th ed., pp. 113-132). Urbana, IL: Univ. of Illinois.

Fox, R. H., Roth, G. W., Iversen, K. V., \& Piekielek, W. P. (1989). Soil and tissue nitrate tests compared for predicting soil nitrogen availability to corn. Agronomy Journal, 81, 971-974.

Gelderman, R. H., \& Beegle, D. (2015). Nitrate-nitrogen. In M. Nathan \& R. Gelderman (Eds.), Recommended chemical soil test procedures for the North Central Region (pp. 51-54). North Central Regional Res. Publ. no. 221 (revised Aug 2015). Columbia, MO: Missouri Agric. Exp. Station.

Helmers, M. J., Zhou, X., Baker, J. L., Melvin, S. W., \& Lemke, D. W. (2012). Nitrogen loss on tile-drained Mollisols as affected by nitrogen application rate under continuous corn and corn-soybean rotation systems. Canadian Journal of Soil Science, 92, 493-499. https://doi.org/10.4141/CJSS2010-043

Jokela, W. E., \& Randall, G. W. (1989). Corn yield and residual soil nitrate as affected by time and rate of nitrogen application. Agronomy Journal, 81, 720-726. https://doi.org/10.2134/ agronj1989.00021962008100050004x

Khan, S. A., Mulvaney, R. L., \& Hoeft, R. G. (2001). A simple soil test for detecting sites that are nonresponsive to nitrogen fertilization. Soil Science Society of America Journal, 65, 1751-1760. https://doi.org/ 10.2136/sssaj2001.1751

Kitchen, N. R., Shanahan, J. F., Ransom, C. J., Bandura, C. J., Bean, G. M., Camberato, J. J., ... Shafer, M. (2017). A public-industry partnership for enhancing corn nitrogen research and datasets: Project description, methodology, and outcomes. Agronomy Journal, 109, 2371-2388. https://doi.org/10.2134/agronj2017.04.0207

Kuzyakova, I. F., Turyabahika, F. R., \& Stahr, K. (2006). Time series analysis and mixed models for studying the dynamics of net $\mathrm{N}$ mineralization in a soil catena at Gondelsheim (S-W Germany). Geoderma, 136, 803-818. https://doi.org/10.1016/j.geoderma.2006.06.003

Lory, J. A., \& Scharf, P. C. (2003). Yield goal versus delta yield for predicting fertilizer nitrogen need in corn. Agronomy Journal, 95, 994 999. https://doi.org/10.2134/agronj2003.0994

Ma, B. L., \& Wu, T. Y. (2008). Plant-available nitrogen in the soil: Relationships between preplant and pre-sidedress nitrate tests for corn production. Journal of Plant Nutrition and Soil Science, 171, 458465. https://doi.org/10.1002/jpln.200700091

Magdoff, F. (1991). Understanding the Magdoff pre-sidedress nitrate test for corn. Journal of Production Agriculture, 4, 297-305. https://doi. org/10.2134/jpa1991.0297

Magdoff, F. R., Jokela, W. E., Fox, R. H., \& Griffin, G. F. (1990). A soil test for nitrogen availability in the Northeastern United States. Communications in Soil Science and Plant Analysis, 21, 1103-1115.

Magdoff, F. R., Ross, D., \& Amadon, J. (1984). A soil test for nitrogen availability to corn. Soil Science Society of America Journal, 48, 1301-1304.

Meisinger, J. J., Bandel, V. A., Angle, J. S., O’Keefe, B. E., \& Reynolds, C. M. (1992). Presidedress soil nitrate test evaluation in Maryland. Soil Science Society of America Journal, 56, 1527-1532. https://doi. org/10.2136/sssaj1992.03615995005600050032x

McCasland, M., Trautmann, N. M., Porter, K. S., \& Wagenet, R. J. (2012). Nitrate health effects in drinking water. Cornell University Cooperative Extension. Retrieved from http://psep.cce.cornell.edu/ facts-slides-self/facts/nit-heef-grw85.aspx (accessed 7 Jan. 2020).

Morris, T. F., Murrell, T. S., Beegle, D. B., Camberato, J. J., Ferguson, R. B., Grove, J., ... Yang, H. (2018). Strengths and limitations 
of nitrogen rate recommendations for corn and opportunities for improvement. Agronomy Journal, 110, 1-37. https://doi.org/10. 2134/agronj2017.02.0112

Mulvaney, R. L., Khan, S. A., Hoeft, R. G., \& Brown, H. M. (2001). A soil organic nitrogen fraction that reduces the need for nitrogen fertilization. Soil Science Society of America Journal, 65, 1164-1172. https://doi.org/10.2136/sssaj2001.6541164x

N'Dayegamiye, A., Whalen, J. K., Tremblay, G., Nyiraneza, J., Grenier, M., Drapeau, A., \& Bipfubusa, M. (2015). The benefits of legume crops on corn and wheat yield, nitrogen nutrition, and soil properties improvement. Agronomy Journal, 107, 1653-1665. https://doi.org/ 10.2134/agronj14.0416

Nutrient star. (2018). TED framework tool. Retrieved from http:// nutrientstar.org/ted-framework/ (accessed 2 Feb. 2018).

Nelson, D. W., \& Sommers, L. E. (1996). Total carbon, organic carbon and organic matter. In D. L. Sparks, A. L. Page, P. A. Helmke, \& R. H. Loeppert (Eds.), Methods of soil analysis. Part 3. Chemical methods (pp. 961-1010). SSSA Book Ser. 5.3. Madison, WI: ASA and SSSA. https://doi.org/10.2136/sssabookser5.3.c34

Nyiraneza, J., N'Dayegamiye, A., Chantigny, M. H., \& Laverdière, M. R. (2009). Variations in corn yield and nitrogen uptake in relation to soil attributes and nitrogen availability indices. Soil Science Society of America Journal, 73, 317-327. https://doi.org/10.2136/sssaj2007. 0374

Orcellet, J., Reussi Calvo, N. I., Sainz Rozas, H. R., Wyngaard, N., \& Echeverría, H. E. (2017). Anaerobically incubated nitrogen improved nitrogen diagnosis in corn. Agronomy Journal, 109, 291-298. https:// doi.org/10.2134/agronj2016.02.0115

Randall, G. W., Vetsch, J. A., \& Huffman, J. R. (1996). Nitrogen and manure management for corn after alfalfa in Winona County (pp. 77-79). Soil Ser. 142. St. Paul, MN:Univ. Minnesota Extension.

Randall, G. W., Vetsch, J. A., \& Huffman, J. R. (2003). Nitrate losses in subsurface drainage from a corn-soybean rotation as affected by time of nitrogen application and use of nitrapyrin. Journal of Environmental Quality, 32, 1764-1772.

Rehm, G., Schmitt, M., \& Eliason, R. (2002). Using the soil nitrate test in Minnesota. St Paul, MN:Nutr. Manag. Univ. Minnesota Extension.

Reussi Calvo, N. I., Rozas, H. Sainz, Echeverría, H., \& Berardo, A. (2013). Contribution of anaerobically incubated nitrogen to the diagnosis of nitrogen status in spring wheat. Agronomy Journal, 105, 321-328. https://doi.org/10.2134/agronj2012. 0287

Ribaudo, M., Delgado, J., Hansen, L., Livingston, M., Mosheim, R., \& Williamson, J. (2011). Nitrogen in agricultural systems: Implications for conservation policy. Economic Research Report No. (ERR127). Washington, DC: ERS USDA. Retrieved from https://www.ers. usda.gov/publications/pub-details/?pubid $=44919$ (accessed 7 Jan. 2020).

Roberts, T., Ross, W., Norman, R., Slaton, N., \& Wilson, C. (2011). Predicting nitrogen fertilizer needs for rice in Arkansas using alkaline hydrolyzable-nitrogen. Soil Science Society of America Journal, 75, 1161-1171. https://doi.org/10.2136/sssaj2010.0145

Ros, G. H., Temminghoff, E. J. M., \& Hoffland, E. (2011). Nitrogen mineralization: A review and meta-analysis of the predictive value of soil tests. European Journal of Soil Science, 62, 162-173. https:// doi.org/10.1111/j.1365-2389.2010.01318.x

Russell, C. A., Dunn, B. W., Batten, G. D., Williams, R. L., \& Angus, J. F. (2006). Soil tests to predict optimum fertilizer nitrogen rate for rice. Field Crops Research, 97, 286-301. https://doi.org/10.1016/j. fcr.2005.10.007

Saha, U. K., Sonon, L., \& Biswas, B. K. (2018). A comparison of diffusion-conductimetric and distillation-titration methods in analyzing ammonium- and nitrate-nitrogen in the $\mathrm{KCl}$-extracts of Georgia soils. Communications in Soil Science and Plant Analysis, 49, 63-75. https://doi.org/10.1080/00103624.2017.1421647

Sainz Rozas, H., Calvino, P. A., Echeverría, H. E., Barbieri, P. A., \& Redolatti, M. (2008). Contribution of anaerobically mineralized nitrogen to the reliability of planting or presidedress soil nitrogen test in maize. Agronomy Journal, 100, 1020-1025. https://doi.org/ 10.2134/agronj2007.0077

Sainz Rozas, H., Echeverria, H. E., Studdert, G. A., \& Dominguez, G. (2000). Evaluation of the presidedress soil nitrogen test for no-tillage maize fertilized at planting. Agronomy Journal, 92, 1176-1183. https: //doi.org/10.2134/agronj2000.9261176x

Schmitt, M. A., \& Randall, G. W. (1994). Developing a soil nitrogen test for improved recomendations for corn. Journal of Production Agriculture, 7, 328-334. https://doi.org/10.2134/jpa1994.0328

Schmitt, M. A., Randall, G. W., \& Rehm, G. W. (2002). A soil nitrogen test option for $N$ recommendations with corn. St. Paul, MN: Univ. Minnesota Extension.

Soil Survey Staff. (2014). Kellogg soil survey laboratory methods manual. Soil survey investigations report no. 42. Version 5.0. R. Burt and Soil Survey Staff, editors. Washington, DC: USDA, Natural Resources Conservation Service.

Struffert, A. M., Rubin, J. C., Fernández, F. G., \& Lamb, J. A. (2016). Nitrogen management for corn and groundwater quality in Upper Midwest irrigated sands. Journal of Environmental Quality, 45, 1557-1564. https://doi.org/10.2134/jeq2016.03.0105

Tonitto, C., David, M. B., \& Drinkwater, L. E. (2006). Replacing bare fallows with cover crops in fertilizer-intensive cropping systems: A meta-analysis of crop yield and $\mathrm{N}$ dynamics. Agriculture Ecosystems and Environment, 112, 58-72. https://doi.org/10.1016/j.agee.2005. 07.003

Tremblay, N., Bouroubi, Y. M., Bélec, C., Mullen, R. W., Kitchen, N. R., Thomason, W. E., ... Ortiz-Monasterio, I. (2012). Corn response to nitrogen is influenced by soil texture and weather. Agronomy Journal, 104, 1658-1671. https://doi.org/10.2134/agronj2012.0184

USEPA. (2018). Inventory of U.S. greenhouse gas emissions and sinks: 1990-2016 Executive summary. Washington, DC: USEPA.

Vinten, A. J. A., Vivian, B. J., Wright, F., \& Howard, R. S. (1994). A comparative study of nitrate leaching from soils of differing textures under similar climatic and cropping conditions. Journal of Hydrology, 159, 197-213. https://doi.org/10.1016/0022-1694(94) 90256-9

Van Wart, J., van Bussel, L. G. J., Wolf, J., Licker, R., Grassini, P., Nelson, A., ... Cassman, K. G. (2013). Use of agro-climatic zones to upscale simulated crop yield potential. Field Crops Research, 143, 44-55. https://doi.org/10.1016/j.fcr.2012.11.023

Waring, S. A., \& Bremner, J. M. (1964). Ammonium production in soil under waterlogged conditions as an index of nitrogen availability. Nature, 201, 951-952. https://doi.org/10.1038/201951a0

Williams, J. D., Crozier, C. R., White, J. G., Sripada, R. P. and Crouse, D. A. (2007). Comparison of soil nitrogen tests for corn fertilizer recommendations in the humid southeastern USA. Soil Science Society of America Journal, 71, 171-180. https://doi.org/10.2136/sssaj2006. 0057 
Yost, M. A., Coulter, J. A., Russelle, M. P., Sheaffer, C. C., \& Kaiser, D. E. (2012). Alfalfa nitrogen credit to first-year corn: Potassium, regrowth, and tillage timing effects. Agronomy Journal, 104, 953962. https://doi.org/10.2134/agronj2011.0384

Yost, M. A., Russelle, M. P., \& Coulter, J. A. (2013). Nitrogen requirements of first-year corn following alfalfa were not altered by fallapplied manure. Agronomy Journal, 105, 1061-1069. https://doi.org/ 10.2134/agronj2012.0496

Zebarth, B. J., \& Paul, J. W. (1997). Growing season nitrogen dynamics in manured soils in south coastal British Columbia: Implications for a soil nitrate test for silage corn. Canadian Journal of Soil Science, 77, 67-76. https://doi.org/10.4141/S96-028

Zebarth, B. J., Younie, M., Paul, J. W., \& Bittman, S. (2002). Evaluation of leaf chlorophyll index for making fertilizer nitrogen recom- mendations for silage corn in a high fertility environment. Communications in Soil Science and Plant Analysis, 33, 665-684. https:// doi.org/10.1081/CSS-120003058

How to cite this article: Clark JD, Fernández FG, Veum KS, et al. Adjusting corn nitrogen management by including a mineralizable-nitrogen test with the preplant and presidedress nitrate tests. Agronomy Journal. 2020;112:3050-3064.

https://doi.org/10.1002/agj2.20228 